\title{
LETS
}

\author{
Journal of Linguistics and English Teaching Studies \\ ISSN (print) : 2715-4408 \\ ISSN (online) : 2715-4416 \\ Homepage : https://jurnal.stainmajene.ac.id/index.php/lets/
}

\section{An Analysis of Students' Ability in Writing Analytical Exposition Text}

\author{
Reski', Nurhaspiah², Uswatunnisa ${ }^{3}$, Rabiatul Adawiah4 \\ Sekolah Tinggi agama Islam Negeri Mejene \\ reski14102000@gmail.com¹, nurhaspia12@gmail.com², uswatunnisa@stainmajene.ac.id ${ }^{3}$, \\ rabiatuladawiah@stainmajene.ac.id ${ }^{4}$
}

\begin{abstract}
This study aims to determine the ability to write an English analytical exposition text in class XI Religion 2 MAN 2 Polewali. Therefore, the main problem is how the students' ability to write analytical exposition texts in class XI Agama 2. This research is quantitative and descriptive. The population in this study were students of class $X I$ Religion 2 MAN Polewali. This means that the population is 15 students, and this population is used as a sample of 15 students. In collecting the data, the researcher used a writing test. Students are asked to make an analytical exposition text. Analysis of student score data found that students' ability in writing analytical exposition texts was still lacking in class XI (15 students). In this case, in class XI, Religion 2, there were no students who got "very good" scores. Six students got the same student's work. The results of this study indicate that the ability to write analytical exposition texts is not capable with students' writing results below the average, and the researchers also found that students' writing results are considered impure because of the indications that students take them from the internet. This is indicated by the use of vocabulary used in addition to the results of interviews with the teacher. The researcher found that there was no guidance from the teacher to the students on how to write analytically. The teacher's exposition text only directs students to look for the structure of the analytical exposition text.
\end{abstract}

Keywords: Writing, Writing Ability And Analytical Exposition

\section{Introduction}

English is an international language that is used as a communication tool in everyday life and in the academic world. In Indonesia, English as a foreign language is taught formally in schools from junior high school to university level. It has become a compulsory subject. In addition, there are many elements in English, such as reading, speaking, listening, and writing. Writing is an activity to convey something using language through writing, with certain intentions and considerations to achieve something desired. "Writing," as defined by the term, is an activity in which characters are used to create a note or information on a medium.

Writing will continue to be valuable in the world of education because it allows people to think more easily. Writing is a very powerful learning tool, and it plays an important role in the world of education. Therefore, in addition to pouring ideas, other elements such as reviewing in terms of speech, vehicle, and arrangement must be followed. Meanwhile, according to Dewi Kusumaningsih (2013), writing is indeed a form of thinking, but it is thinking for certain responders and for certain situations. In the process of teaching and learning English in schools, writing skill are categorized as language skills that must be mastered by students, meaning that they require a lot of vocabulary in composing paragraphs. 
As we must believe, writing is the most crucial and challenging skill in the language. Which means the teacher should enjoy the activities and have the related hobbies. Actually, writing is not an easy activity to do for the purpose of sharing information. Writing plays an important role for students who are in the process of learning a language. In Indonesia, students are required to learn to write different text types. Analyzing a text is one way that can be used by the teacher to determine the students' ability in writing

However, many studies have been conducted in Indonesia on students' ability to write various types of texts. Therefore, in this study, the researcher wanted to know the students' ability in writing text-analytical exposition. An analytical exposition is a text that elaborates the writer's idea about the phenomenon it' surrounds. According to Nurhikmah and April, analytical exposition texts involve students mastering the topic in order to provide arguments as support. This means that students must gain some knowledge that will be used to analyze the topic.

In senior high school, the analytical exposition text is one of the texts that is learned by the eleventh-grade students. Nevertheless, the students usually faced difficulty in writing analytical exposition text. Man 2 Polewali is a school that uses 2013-based (K-13) in the process of teaching and learning English. English is taught two times a week (90 minutes) and the passing grade for the English subject is 75 in the eleventh grade. Based on the description above, the researcher thinks that the importance of this research lies in being able to improve students' ability to understand analytical exposition text properly and correctly. The researcher conducted research entitled "Analysis of students' Ability in Writing Analytical Exposition Text at XI Grade of MAN 2 Polman.

The use of the guiding questions technique in increasing students' writing of analytical exposition text in the second grade of SMA Negeri 1 Natar. This study was conducted by Nabilla Marsya (2018). In this research, the researcher administered five meetings. At the beginning of the meeting, the researcher conducted a pretest to find out the students' initial ability in writing analytical exposition texts. The researcher then held three treatment time meetings.At the end of the meeting, the researcher conducted the posttest to find out the students' writing ability after having the treatments that used the guiding questions technique.

The purpose of this study was to improve the students' ability to write textual analytical expositions through the guiding question technique. The subjects of this study were 35 students in one of the SMA Negeri 1 Natar. The results of this study indicate that there is an increase in students' writing abilities to write analytical text from pre-test to posttest after being taught through the Guiding Questions technique.

Rifa'atul Mahmudah (2015) found that the descriptive research that aims to analyze how students' writing in analytical exposition texts is seen from the structure of the analytical exposition text itself, namely the thesis, argument, and reiteration. In this study, the author used an assessment rubric adapted from the Hamp-Lyons theory, which is used by a team of assessors who are experts in writing and the author himself to assess the student's writing. The instrument used is writing analytical exposition text based on three different topics. This research was conducted at MAN 2 Padang for class XII students in the $2015 / 2016$ academic year. The number of student writings collected is 100 texts, and 25 texts are taken randomly as a sample for analysis. The results of the analysis show that the students' ability to write theses, arguments, and reiterations is included in the good category. For better results, English teachers are expected to provide more writing exercises to students for various types of texts in English, especially analytical exposition texts. 
Furthermore, this research can be used as a reference to develop research related to better analytical exposition texts in the future.

In teaching writing on analytical exposition text at the senior high school level was effective. This technique is used to help the students organize their ideas. In addition, it allows the students to share and exchange their ideas or information, which can be corrected by their peers in a pair group discussion. Students can improve their critical and analytical thinking skills by correcting each other's work. Students may also gain confidence and interest since their writing is corrected by their peers. Besides, the students can also take part actively. By applying the Peer Correction Technique in writing analytical exposition text, the teacher can achieve the goal of teaching analytical exposition text to senior high school students. In other words, this technique can assist teachers in instructing students on how to write analytical exposition texts.

Based on the statement above, it can be concluded that there are several ways to improve students' writing skills. Therefore, the researcher used a writing test for students to improve their ability in writing analytical exposition texts. Students can write well if they know and apply writing techniques.

\section{Method}

The design of this research was descriptive quantitative research. Quantitative research will be used to analyze the students' abilities in writing analytical exposition texts, which include developing ideas, organizing ideas, grammar, vocabulary, and mechanics. The research will be carried out at XI Grade of MAN 2 Polewali Mandar as the research participants.

The researchers would conduct the research in class XI grade of MAN 2 Polewali. In this school, there are five classes, yet the researcher has chosen only one class, Agama 1 class. The reason why the researchers took it because it is the superior class among the other classes, which consist of 15 students. The teacher teaches without giving practice, so some students do not understand the analytical exposition itself. Data for this research will be collected by using writing test, observation and interview. The techniques are described in the following scenario:

Writing tests are used to assess students' abilities. In this study, the researchers used tests to collect data on students' writing. The test given is a written test where students write an analytical exposition text. Besides that, the researchers used Observation and interview.

Observation is a data collection technique in which researchers make observations directly on the object of research in order to look closely at the learning activities in XI grade of MAN 2 Polewali Mandar. While An interview is a form of communication between two or more people involving someone who gets information from another by asking questions based on a specific purpose. An interview can be interpreted as a method used for interviewing a research subject in order to accumulate data.

\subsection{Findings}

Based on the interview results with the teacher, the researcher found that the analytical exposition text is one of the English materials for the $1^{\text {st }}$ semester of class XI Agama 2. The teacher taught using Whatsapp media to teach writing analytical exposition texts. Due to the COVID-19 pandemic in the learning and teaching process, the teacher created a WhatsApp group so that the interaction in the class goes well. However, it turns out that the response from students is very minimal. The teacher found a problem that only 15 of 28 students were active in the teaching and learning process because those 15 
students did not have a mobile phone to join the online class learning. During the learning process, only six students gave some responses to the group.

When the teacher gave assignments to write analytical exposition texts, students just searched on the internet. This was one of the problems faced by the teacher because students were not interested in writing analytical expositions. One of the ways that teachers used to ensure that the students were able to understand and write analytical exposition texts was to search on Google for one sample of analytical exposition text through a WhatsApp group to look for text structures, features, and language.

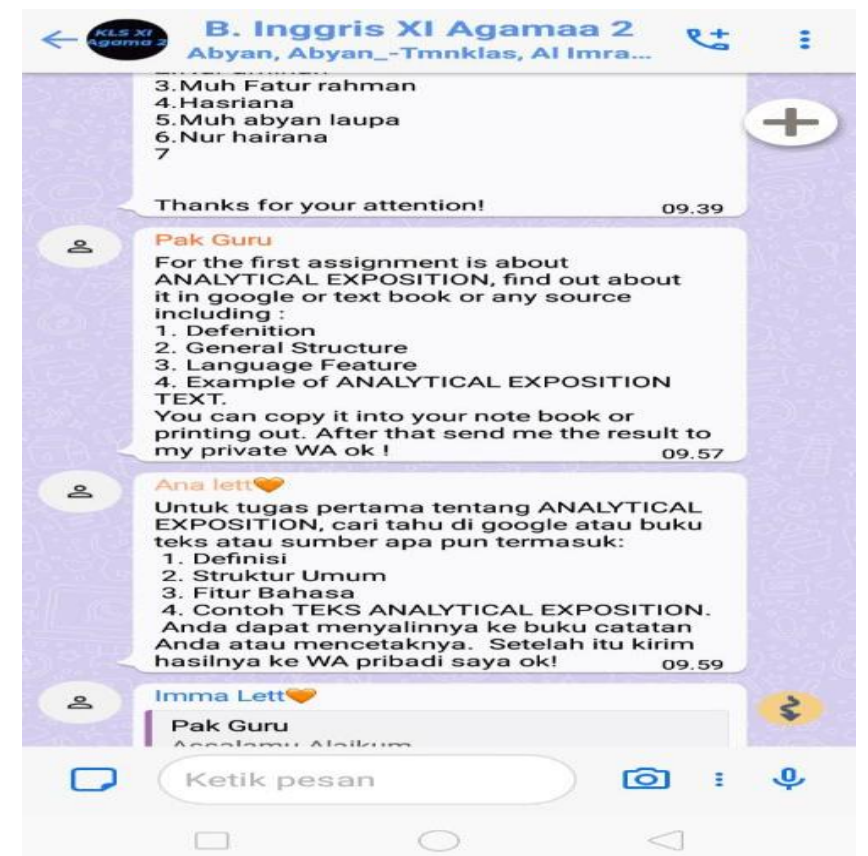

Figure 1. The teacher directs the students to searching

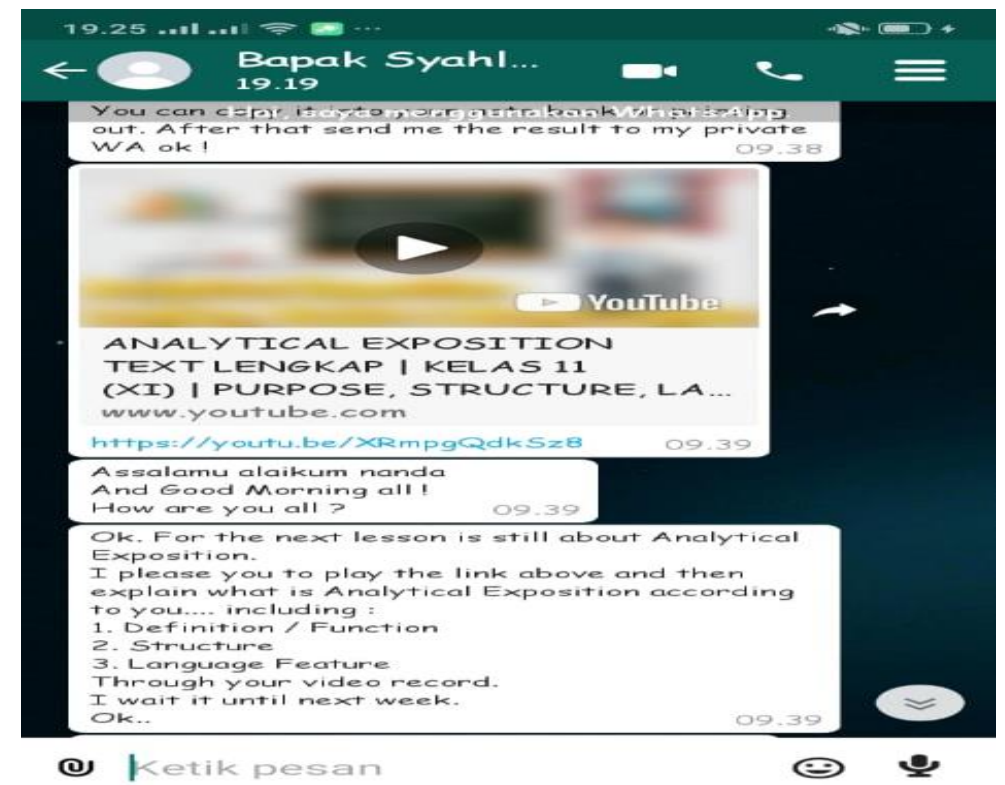

Figure 2. The Teacher never explained to the students 


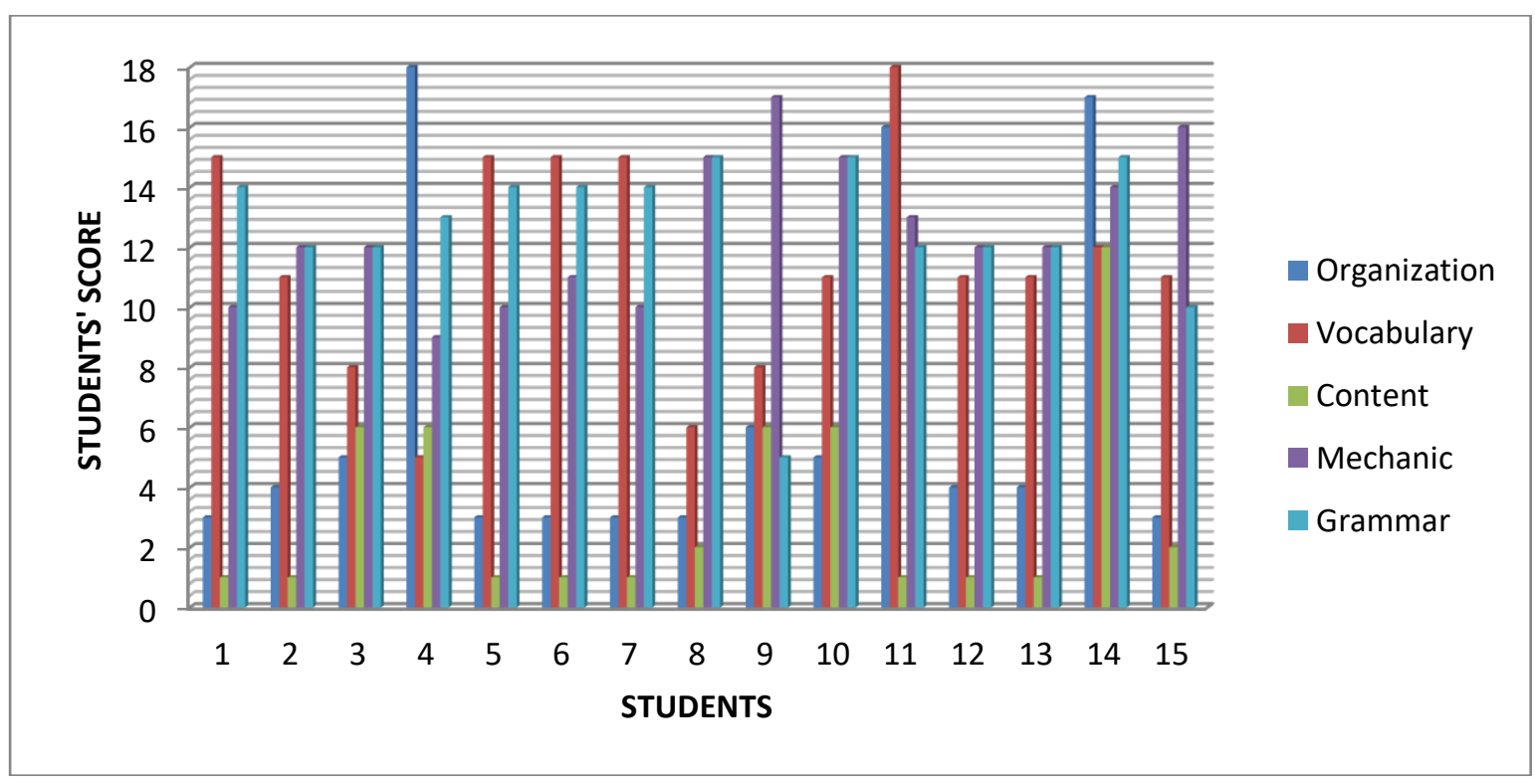

Figure 3. Students' Writing Score

After learning the material for the analytical exposition text, from the results of the students' writing test, the evaluation results show that students' scores in the mechanic assessment rubric have an average of 12.53 in the good category. This shows that the teacher focuses more on the mechanic's section; that is, the teacher only directs students to find their own material, including definitions, general structure, and language features. The high average score in the mechanics section is a natural thing because the teacher always does the same thing at every meeting.

The grammar assessment rubric, with an average result of 12.6 points, is in the good category. This is due to an indication that students are more likely to be able to use language features in compiling a written text because the teacher at every meeting also always does the same thing as in the mechanic's section. Another reason for This grammar section is high because 6 writings are the same as indications of students taking the example of writing analytical exposition text on the internet.

As for the results, the average value of 11.46 is in the good category. Then in the organizational assessment rubric, the average value of 6.4 is in the Fair category. This is because in the learning process, the teacher does not once order students to write an analytical exposition text. In the content section, the average score of 3.2 is in the poor category because, in the learning process, the teacher always gives assignments to students to find definitions, general structures, and language features without asking students to make analytical exposition texts.

\subsection{Discussion}

The results of this study can also be compared with the findings of Marsya (2018). Marsya found an increase in students' writing ability. Di penelitian ini tidak ditemukan adanya peningkatan because it did not use pre and post-tests. However, the evaluation results show that students' scores tend to be low and not murni because there are indications that students take them from the internet. This is indicated by the use of the vocabulary used. This is because there is no guidance according to the results of observation, namely the teacher immediately looks for the structure himself. It can be concluded that MAN 2 requires a guiding questions technique as used by Marsya (2018). 
The research that supports this is research conducted by Elfa (2020). In her research, Elfa used descriptive research. Research data were collected by giving writing assignments. Then, they are given a grade and categorized by a scoring rubric. The researcher founded that the use of the scoring rubric of the study. The collected data were analyzed using quantitative and qualitative analysis. From the data obtained, it can be concluded that students have an unsatisfactory performance in writing analytical exposition texts. This is in line with the results of the research founded by researchers who also use descriptive research using means of scoring. From this score, the researcher also founded that students had unsatisfactory scores from the analytical exposition text because students still took resources from the internet to work on the text.

The results of this study can also be compared with Putri Septi (2020). Putri Septi explained in her research that the experimental method used a quasi-experimental design in two groups to determine whether there was a significant difference in students' writing skills in analytical exposition text using the PIE technique. This increase was not found in this study because it did not use the PIE technique. However, the evaluation results showed that students' scores tended to be low and not original because there were indications that students took them from the internet. This is indicated by the use of the vocabulary used. This is because there is no guidance according to the results of observations, namely the teacher immediately looks for his structure. It can be concluded that MAN 2 requires the PIE technique as used by Putri Septi (2020).

The results of this study can also be compared with those of Aulia Batubara (2017). Aulia Batubara explained that in her research, her study found that the gallery walk technique method was to improve students' ability to write announcements through the gallery walk technique. Teaching students to write announcement text through the gallery walk technique can improve students' ability to write announcement text. This increase was not found in this study because it did not use the gallery walk technique. However, the evaluation results show that students' scores tend to be low and not original because there are indications that students take them from the internet. This is indicated by the use of the vocabulary. This is because there is no guidance according to the results of observations, namely the teacher immediately looks for his structure. It can be concluded that MAN 2 requires a gallery walk technique as used by Aulia Batubara (2017).

Then the results of this study can also be compared with Wulandari (2011). Wulandari explained in his research that the experimental method used the LEET technique to determine whether there was a significant difference between students' analytical exposition text writing skills before and after being taught using the LEET technique to improve their writing skills. However, the evaluation results show that students' scores tend to be low and not original because there are indications that students take them from the internet. This is indicated by the use of the vocabulary. This is because there is no guidance according to the results of observations, namely the teacher immediately looks for his structure. It can be concluded that MAN 2 requires the LEET technique as used by Wulandari (2011).

\section{Conclusion}

As previously described in the results and data analysis, it can be concluded that the findings of observations and interviews about how students' writing skills analytical exposition texts are in

The average results based on the average results in the mechanics section were in the good category, the average results in the grammar section were in the good category, the average results in the vocabulary section were in the good category, the average results 
in the vocabulary section were in the good category, the average results in the organization 6.4 were in the fair category, and the average result in the content 3.2 section was in the poor category. By looking at the average results of students' writing skills, it shows that students do not have the ability to write analytical exposition texts because no one gets a score in the very good category.

\section{References}

Aulia Fahmi Batubara 2017. To improve the students' ability in writing announcement through gallery walk technique of eight grade at MTs jam'iyatul Alwashliyah tembung in academic year 2016/2017.

Annisa Fitri Irwan 2018. How is the students' ability in writing the thesis statement, argumentation, organization and writing, and the use of evidence of analytical exposition text at Universitas Negeri Padang.

David, Nunan . 2003. Practical English Language Teaching. New York: Mc Craw Hill.

Elfa, Fanalisa. 2020. The students had unsatisfactory performance in writing analytical exposition text the students at XI IPA 2 SMAN I Ulakan Tapakis.

Harmer, Jeremy. 2004. How to teach writing (Harlow: Person Education Limited

Anne Whitaker, Academic Writing Guide, (Bratislava: City University of Seattle).

Heaton, J.B. 2014. Writing English Language Tests. New Edition. New York: Longman.

Mayasari, Rina. 2012. Using group Investigation method to improve students' writing ability in analytical exposition text at XI of MA Manahijul Huda Pati.

Muslimin. 2017. The Students'Ability in Writing Analytical Exposition Text in English at XI Senior high school Hangtuah 3 Mataram.

Marsya Nabilla. 2017. The Use of Guiding questions Technique in Increasing Students' Writing of Analytical Exposition Text at the Second Grade of SMA N 1 Natar.

Mayasari, Rina. 2012. Using group Investigation method to improve students' writing ability in analytical exposition text at XI of MA Manahijul Huda Pati.

Muhammad, Hasbi Affan. 2014 Students' Ability in Writing Analytical Exposition Text: A Study at Eleventh Grade Students of SMA 4 Negeri Padang, Jurnal IImiah Mahasiswa STKIP PGRI Sumbar.

Mahmudah, Rifa'atul. 2016. An Analysis of Generic structure in students'Writing of an Analytical Exposition Text at Grade XI MAN Padang in The 2015/2016. Journal Of English Language Teaching Vol 6 No. Seri B.

Nurhikmah lik and Rahayu Apriliaswati. 2013. Improving Students' Analytical Exposition Text Writing, Skills through Guided Prompt-Response Activity, Jurnal Pendidikan Dan Pembelajaran Untar, Vol. 9, No.2, 2013

Najogi, Jonggorta.2017. Using PEER Correction Towards Students' Writing Abilitu in Writing Analytical Exposition Text At Senior High School. Journal of English Language Teaching Vol. 8 No.1.

Pharr, Donald and Shanti V. 2005. Buscemi, Writing Today Contexts and Opinion for the Real World: Brief Edition, (New York: McGraw Hill) 
Septi, Putri Riani. 2020. study the writer did the experimental method by using quasiexperimental design to the two groups the study was eleventh grade students of SMAN 11 Palembang in the academic year 2019/2020.

Sugiarto. 2015. Improving the Students' Writing Ability through Four Square Writing Method at the Second Grade of Datuk Ribandang Junior High School Makassar. Thesis Makassar. UIN Alauddin Makassar.

Sugiono. 2019. Metode penelitian pendidikan Kuantitatif, Kualitatif dan Kombinasi R\&D dan Penelitian Pendidikan,ed, Apri Nuryanto, edisi ke 3, Cet. I (Bandung Alvabet cv, April)

Testi, R., Harmaini, F., and Yandri. 2014. Teaching Writing Analytical Exposition Text by Using Mind Mapping. Bung Hatta University Journal, Vol.3, No.06, 2014.

Utami, Dewi. 2013. How to Write. Medan: Latansa Press

Wulandari, Dewi. 2011. The ability in writing analytical exposition text of the eleventh grade students of SMA N 2 Kudus in the academic year 2011/2012. 